\title{
Hourly interaction between wind speed and energy fluxes in Brazilian Wetlands - Mato Grosso - Brazil
}

\author{
THIAGO R. RODRIGUES ${ }^{1}$, LEONE F.A. CURADO ${ }^{1}$, VINICIUS M.R. \\ PEREIRA $^{1,2}$, LUCIANA SANCHES ${ }^{1,3}$ and JOSÉ S. NOGUEIRA ${ }^{1}$ \\ ${ }^{1}$ Programa de Pós-Graduação em Física Ambiental, Instituto de Física, Universidade Federal de Mato \\ Grosso, Av. Fernando Corrêa da Costa, 2367, Boa Esperança, 78060-900 Cuiabá, MT, Brazil \\ ${ }^{2}$ Instituto Nacional de Pesquisas Espaciais/INPE, Av. Dr. Hélio Ponce de \\ Arruda, s/n, Bosque da Saúde, 78050-911 Cuiabá, MT, Brazil \\ ${ }^{3}$ Departamento de Engenharia Sanitária e Ambiental, Universidade Federal de Mato Grosso, Av. \\ Fernando Corrêa da Costa, 2367, Boa Esperança, 78060-900 Cuiabá, MT, Brazil \\ Manuscript received on February 23, 2015; accepted for publication on July 5, 2016
}

\begin{abstract}
Matter and energy flux dynamics of wetlands are important to understand environmental processes that govern biosphere-atmosphere interactions across ecosystems. This study presents analyses about hourly interaction between wind speed and energy fluxes in Brazilian Wetlands - Mato Grosso - Brazil. This study was conducted in Private Reserve of Natural Heritage (PRNH SESC, 16039'50"S; 56 47 '50"W) in Brazilian Wetland. According to Curado et al. (2012), the wet season occurs between the months of January and April, while the June to September time period is the dry season. Results presented same patterns in energies fluxes in all period studied. Wind speed and air temperature presented same patterns, while LE was relative humidity presented inverse patterns of the air temperature. LE was predominant in all seasons and the sum of LE and $\mathrm{H}$ was above $90 \%$ of net radiation. Analyses of linear regression presented positive interactions between wind speed and LE, and wind speed and $\mathrm{H}$ in all seasons, except in dry season of 2010. Confidence coefficient regression analyses present statistical significance in all wet and dry seasons, except dry season of 2010, suggest that LE and $\mathrm{H}$ had interaction with other micrometeorological variables.
\end{abstract}

Key words: Energy balance, latent heat flux, linear regression, micrometeorology, Pantanal, sensible heat flux.

\section{INTRODUCTION}

The state of Mato Grosso contains three of main biomes of South America: the Amazon rainforest, the Cerrado (or savanna) and the Pantanal wetland (Rodrigues et al. 2013, 2014) The last two biomes have gained attention from researchers studying

Correspondence to: Thiago R. Rodrigues

E-mail: thiagorangel@pgfa.ufmt.br phenomena which promote balance between human and environmental activities. Because of the flow dynamics of matter and energy in these biomes, the cerrado and Pantanal are highly relevant for gaining a deeper understanding of environmental processes that govern the biosphere-atmosphere interactions across ecosystems (Curado et al. 2016, Rodrigues et al. 2016). 
The Pantanal is a complex ecological mosaic that contains large areas of woody vegetation that are subject to periodic inundation, including areas of invasive trees dominated by Vochysia divergens (Vochysiaceae), Scheelea phalerata (Arecaceae), Anadenanthera macrocarpa and Astronium urundeuva (Anacardiaceae), Bromelia sp. (Bromeliaceae), Guadua sp. (Taboca/Poaceae), Attalea phalerata, Copernicia alba, Combretum laxum, and Byrsonima orbignyana (Haase and Haase 1995, Damasceno-Júnior et al. 2005, Junk et al. 2006).

Climate and vegetation strongly influence the water cycle from local to regional scales. In addition to impacts on the partition of energy balance in the region, changes in surface energy and water balance can have a significant impact on local water availability, especially in dry climatic regions (Lenters et al. 2011).

The quantification of latent heat (LE) and sensible heat $(\mathrm{H})$ by the Bowen ratio method have been widely used in the last decade, mainly for determining the energy balance for studies on energy dynamics of forest and management availability of water for certain crops by ET (Alves and Pereira 2000, Hayashi et al. 2002, Chen et al. 2009, Giambelluca et al. 2009, Rodrigues et al. 2013).

The energy balance is based on the principle of conservation of energy and relate energy flow densities available in the vegetation (net radiation) to energy use, especially in the evaporation LE and $\mathrm{H}$ with noted variations of air temperature and soil (Pereira et al. 2002, Rodrigues et al. 2014). Micrometeorological methods can quantify these flows and assess the transformation of radiant energy into LE and $\mathrm{H}$, thus representing the accounts of these interactions.

$\mathrm{LE}$ and $\mathrm{H}$ are important parameters that directly drive variations in climate and can, in turn, alter the environmental variables driving mass and energy exchanges between the ground and the atmosphere (Falge et al. 2005, Rodrigues et al. 2013). Thus, LE and H fluxes are important variables in meteorological, hydrological and ecological analyses. By dividing energy flux components into $\mathrm{LE}$ and $\mathrm{H}$, we can determine the water vapor and heat content of the atmosphere and, by extension, better understand regional and global scale climatological processes (Rodrigues et al. 2016).

Local wind speed variations lead to spatially varying turbulent heat fluxes, which can be significantly under or overestimated if the spatial variations in wind speed are neglected. While this is qualitatively known, most applications of distributed hydrological energy-balance (EB) models neglect the systematic influence of local terrain on wind speed variations (Dadic et al. 2013). Marks and Dozier (1992) and Marks and Winstral (2001) found that higher wind speed at wind-exposed sites leads to a significant increase $(30 \%)$ in turbulent fluxes and therefore to higher mass fluxes than at sheltered sites with low wind speed.

At present, the current knowledge on wetland ecosystem energy balance is confined to temperate, boreal, and arctic zones, with data principally collected only during the growing season. Little is known about energy exchanges in wetlands of the tropics and subtropics where seasonality is best characterized by wet and dry seasons. The potential for year-round plant growth at low latitudes is likely to affect wetland energy balance differently during wet and dry periods of the year, as has been observed in some tropical terrestrial ecosystems (Malhi et al. 2002, Von Randow et al. 2004, Vourlitis et al. 2008).

Energy, water, and carbon cycles in forest ecosystems are tightly coupled through ET processes (Law et al. 2002, Noormets et al. 2006). Although land managers are more interested in water and carbon balances, quantifying forest energy balance offers insights into how 
management affects the forest microclimate and the feedbacks of land use change to climate change at a regional scale. (Restrepo and Arain 2005, Pielke et al. 2007, Curado et al. 2014, Rodrigues et al. 2014). Uncertainty about the combined consequences of afforestation or deforestation on regional climate and greenhouse gas emissions indicates the need for more research on the physical effects of forest management (Da Rocha et al. 2004, Bala et al. 2007, Juang et al. 2007).

According to Sanches et al. (2011), the high rates of ET are due in part to high water availability, even during the dry season, as well as the consistently high leaf area index (LAI) values of the Vochysia divergens, Pohl canopy that increases the transpiration surface area during the dry season when the water table is below the soil surface. Future research should aim to better quantify these impacts by expanding measurements to wetland areas that have not yet been invaded by Vochysia divergens, Pohl, and by modeling the future spread.

The purpose of this study is to evaluate the hourly interaction between wind speed and energy fluxes in Brazilian Wetlands - Mato Grosso Brazil.

\section{MATERIALS AND METHODS}

\section{STUDY AREA}

This study was conducted in an area located in the Private Reserve of Natural Heritage (PRNH SESC) Pantanal of Barão de Melgaço, Mato Grosso, Brazil located $160 \mathrm{~km}$ south of Cuiabá. A micrometeorological tower was installed at a height of $32 \mathrm{~m}$ (16039'50"S, 56 47' $50^{\circ}$ ' W) and 120 $\mathrm{m}$. The area's vegetation is dominantly Vochysia divergens, Pohl, locally known as cambarazal, with canopy heights ranging from 28 to $30 \mathrm{~m}$.

\section{MICROMETEOROLOGICAL MEASUREMENTS}

Net radiation was measured using a net radiometer (Kipp \& Zonen Delft, Inc., Holland), and the soil heat flux was measured using two fluxmeters (HFT-3.1, REBS, Inc., Seattle, Washington) installed at $0.05 \mathrm{~m}$ and $0.25 \mathrm{~m}$ depths. The gradients of temperature and humidity were estimated for two thermohygrometer (HMP 45C, Vaisala, Inc., Helsinki, Finland) installed at $33.7 \mathrm{~m}$ and $37.7 \mathrm{~m}$ height from the micrometeorological tower. Wind speed was measured using a anemometer - A-014 wind speed Sensor Met One Instruments, Inc., USA.

\section{CALCULATIONS}

The energy balance equation was used as an alternative for obtaining data of LE flux. According to Amiro (2009), LE obtained from energy balance is a viable option when good data is available (Rodrigues et al. 2013). The energy balance is shown in equation 1 . However, the portions intended for photosynthesis (P) and store energy in the vegetation (S) may be disregarded (Rodrigues et al. 2013) because the magnitude is much smaller than the other portions, as equation (2).

$$
\begin{aligned}
& R n=L E+H+G+P+S \\
& L E=R n-H-G
\end{aligned}
$$

Where $\mathrm{Rn}$ is net radiation, $\mathrm{LE}$ is the latent heat flux, $H$ the sensible heat flux, and $G$ the soil heat flux. All variables are expressed in $\mathrm{Wm}^{-2}$.

$\mathrm{H}$ was obtained using the Bowen ratio method (equation 3). Errors in the estimated values were minimized using conditions proposed by Perez et al. (1999, 2008).

$$
\begin{aligned}
& H=\left(R_{n}-G\right) \frac{\beta}{(\beta+1)} \\
& \beta=\gamma \frac{\Delta T}{\Delta e}
\end{aligned}
$$

Where $\beta$ is the Bowen ratio (equation 4 ), $\Delta \mathrm{T}$ is temperature difference $\left({ }^{\circ} \mathrm{C}\right)$ between two heights, $\Delta \mathrm{e}$ is the vapor pressure difference $(\mathrm{kPa})$ and $\gamma$ is the psychrometric constant $\left(\mathrm{kPa} .{ }^{\circ} \mathrm{C}^{-1}\right)$. 


\section{STATISTIC}

In interactions analyses between wind speed, LE and $\mathrm{H}$ used linear regression, using model type: $\mathrm{y}=$ $a+b x$, where $y$ is dependent variable, $x$ independent variable, $\mathrm{a}$ and $\mathrm{b}$ are regression coefficient.

\section{RESULTS AND DISCUSSION}

\section{MICROCLIMATIC VARIABLES IN WET AND DRY SEASONS}

According to Curado et al. (2012), the wet season occurs between the months of January and April, while the June to September time period is the dry season between the years 2007-2010. Danelichen et al. (2013) obtained precipitation values through an TRMM satellite and detected that Pantanal presents precipitation defined with higher precipitation in wet season and lower or no precipitation in dry season.

Table I presents higher and lower hourly values of energy fluxes ( $\mathrm{Rg}, \mathrm{Rn}, \mathrm{LE}$ and $\mathrm{H})$, in W. $\mathrm{m}^{-2}$, air temperature $(\mathrm{T})$, in ${ }^{\circ} \mathrm{C}$, relative humidity $(\mathrm{RH})$, in $(\%)$ and wind speed (U), in $\mathrm{m} \cdot \mathrm{s}^{-1}$ in wet and dry seasons between 2007-2010.

Figures 1 and 2 present the seasonal hourly values of micrometeorological data such as wind speed, global radiation $(\mathrm{Rg})$, air temperature (T) and relativity humidity characteristic of the Pantanal ecosystem.

According to Figure 1, we note that the values of global radiation describe the same pattern in all time periods studied: starting around 6 hours and ending around 18 hours with lower values occurring at these times and having its maximum around noon. This pattern is due to the daily period of the Sun, since the solar radiation reaching the surface is dependent on the apparent daily motion of the Sun. The fact that higher values of solar radiation occur near noon is because at this time the sun's rays fall perpendicularly to the surface, because noon is the time when the solar inclination angle is the maximum possible.
The pattern of global radiation affected the patterns of local temperature, we note that during early morning the temperature has lower values, that is because at early morning, the ground surface is a little heated due to heat loss by night soil (Novais et al. 2012), and yet has little radiation reaching the surface in this moment, this pattern is repeated at late afternoon, with the temperature decrease due to decreased overall radiation, but even lowering the temperature value at late afternoon, it still remains higher than the temperature at early morning, because the soil is still heated due to radiation throughout the day, so heating the air. Late afternoon is when the surface soil begins the process of heat loss which remains throughout the night, obeying its daily cycle.

An important factor is to portray the lag in time between the maximum global radiation and the maximum temperature than occurs around 14 hours, the maximum air temperature occurs around two hours after the maximum of the incident solar radiation on the surface, this is because the time for solar radiation interacts with the soil surface. So, soil surface stays heating and it heats the adjacent air layers and thus reaching the layer of air of the measuring equipment, so occurs the lag time between maximum of solar radiation and air temperature.

About relative humidity had inverse pattern of the temperature with higher values in the early morning and lower values coinciding with the maximum air temperature time, it is because according to the laws of thermodynamics to raise the temperature of a given parcel of air, this parcel of air should increase its volume, so that swelling of the air parcel at times of peak temperature decreases the ratio of the water content contained in this parcel of air and the volume of the parcel, thus lowering the relative humidity, at periods when the temperature is lower, like for example, at early morning, this reason has its greatest value causing higher values of relative humidity. 


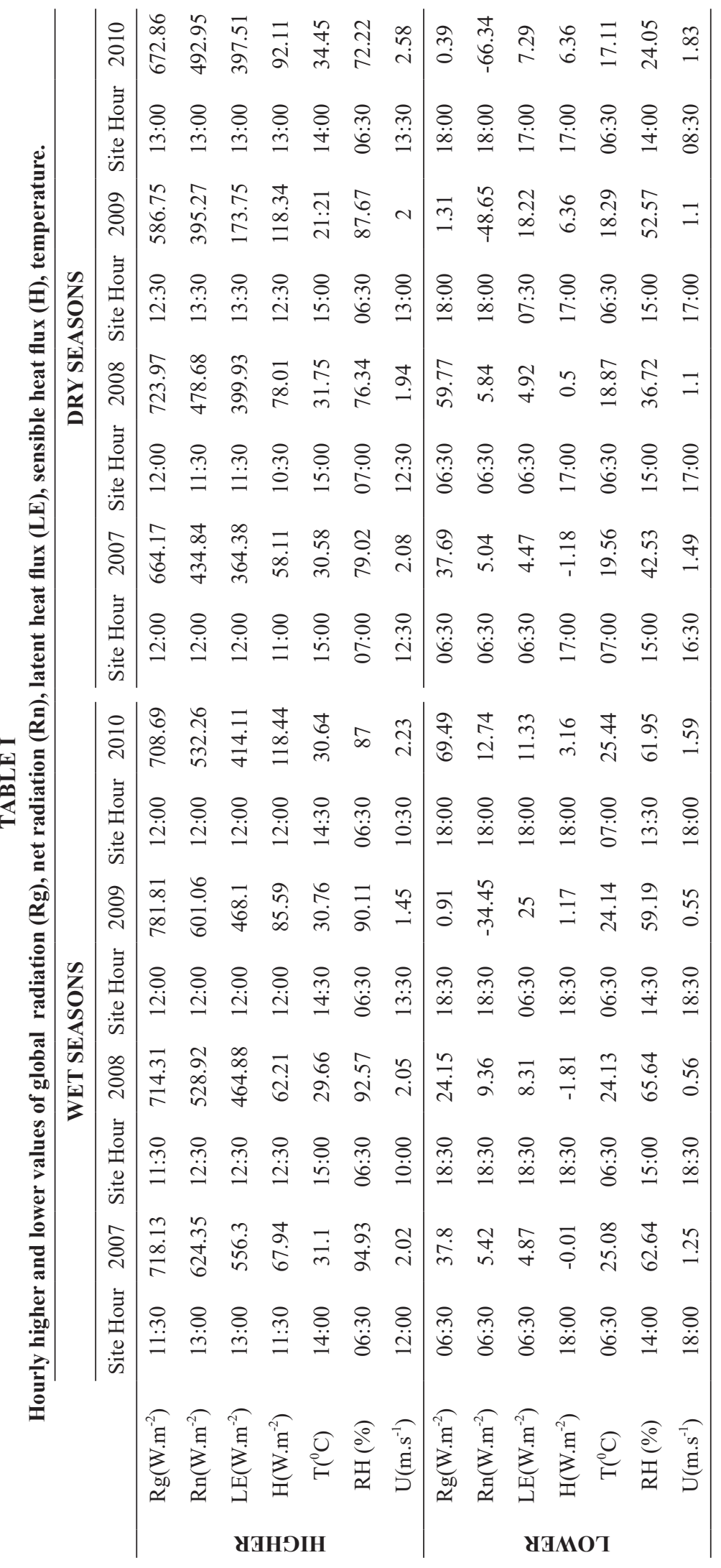




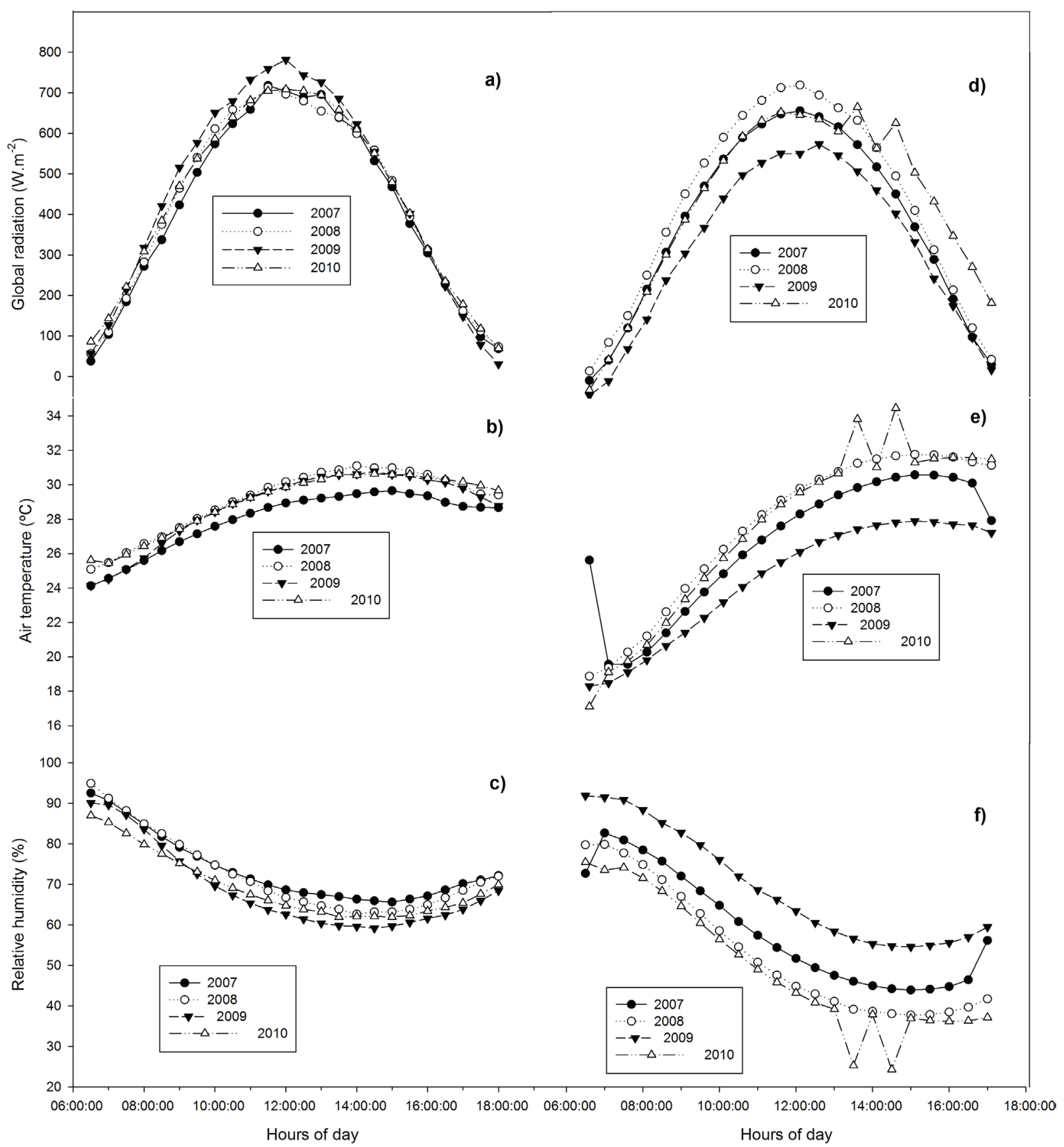

Figure 1 - Patters of the hourly data global radiation $(\mathrm{Rg})$, air temperature $(\mathrm{T})$ and relative humidity in wet and dry seasons for the Brazilian Wetlands in Mato Grosso-Brazil during the study period. Global radiation (a), air temperature (b), and relative humidity (c) in wet seasons between 2008-2010. Global radiation (d), air temperature (e) and relative humidity (f) in dry seasons between 2007-2010.

Figure 2 presents hourly values of wind speed between 2007-2010. Wind speed presents the same air temperature patterns with lower values in early morning and late afternoon, higher values in wind speed occurs between 10:00 and 13:30 in all periods. 


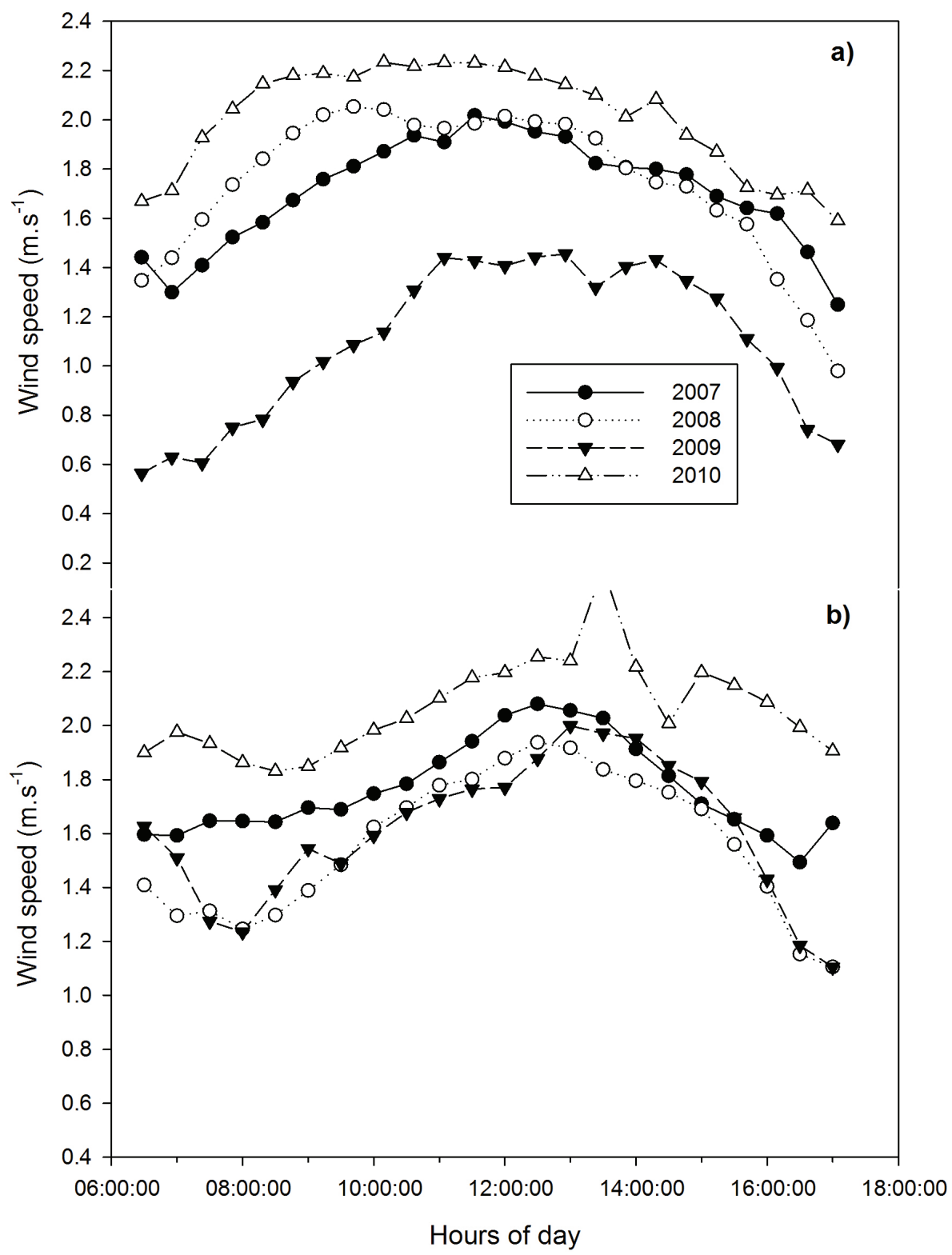

Figure 2 - Patters of the hourly data wind speed in wet and dry seasons for the Brazilian Wetlands in Mato Grosso-Brazil during the study period. (a) Wind speed in wet seasons between 2007-2010. (b) Wind speed in dry seasons between 2007-2010.

HOURLY VARIATIONS IN ENERGIES FLUXES: RN, LE AND H

Figure 3 presents patterns of $\mathrm{Rn}, \mathrm{LE}$ and $\mathrm{H}$ in wet and dry seasons between 2007-2010. These patterns is similar solar radiation patterns (Figure 1 ), note that hourly values is lower in dry seasons, it is due time of year. In local study, dry season occurs between winter and spring, where global radiation is lower, so this factor affects net radiation and energy partition.

According to Figures 4 and 5, LE is prevalent in all periods from 2007 to 2010 , including the dry seasons, indicating that this variable is the most important energy partition in the biome, which it is the largest contribution to the partition of energy Cambarazal. The highest rates of LE during this 


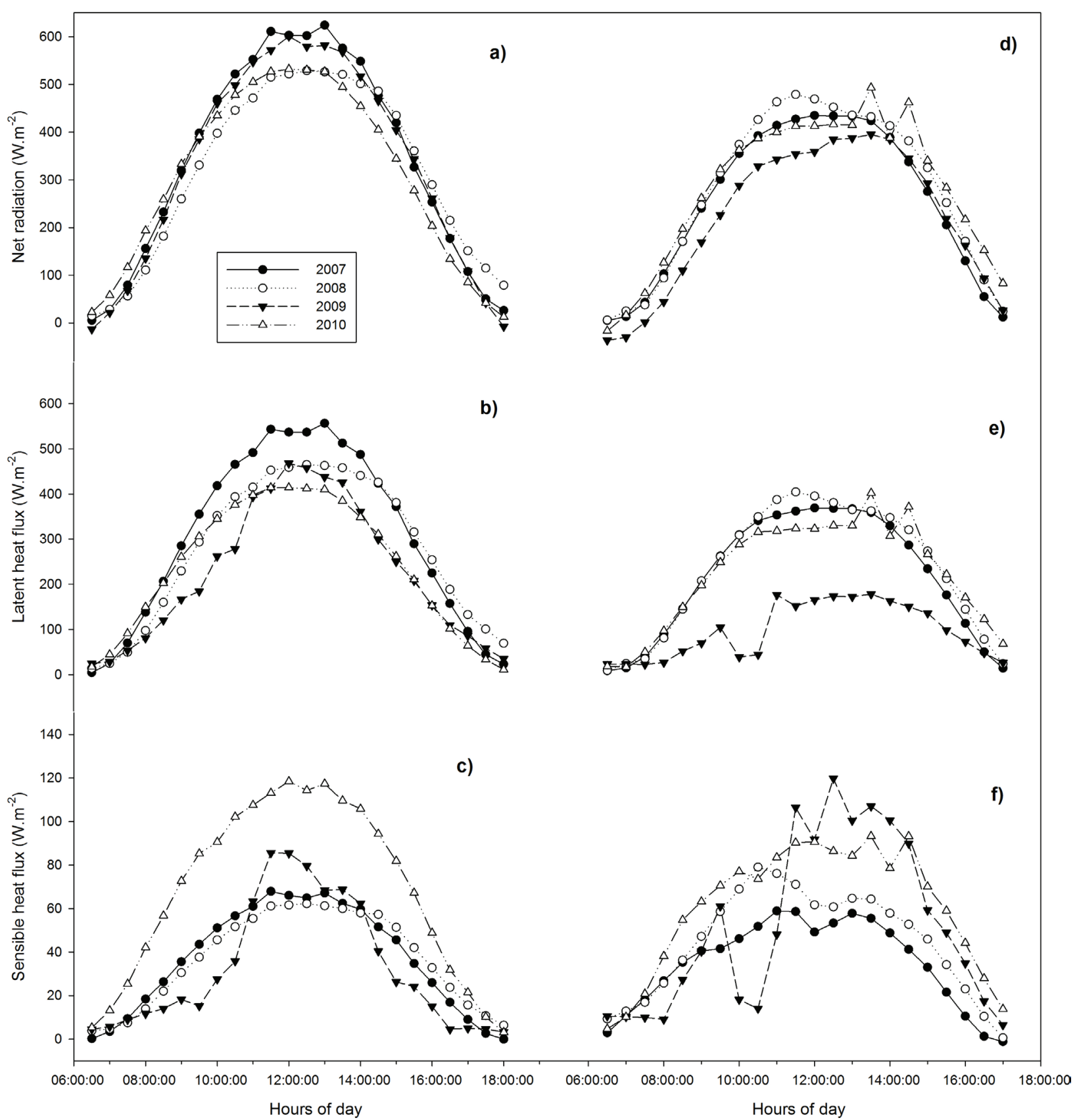

Figure 3 - Patters of the hourly data net radiation (Rn), latent heat flux (LE) and sensible heat flux (H) in wet and dry seasons for the Brazilian Wetlands in Mato Grosso-Brazil during the study period. Net radiation (a), latent flux (b) and sensible heat flux (c) in wet seasons between 2007-2010. Net radiation (d), latent flux (e) and sensible heat flux (f) in dry seasons between 2007-2010.

period reflects the increased availability of soil water due to higher precipitation (Nobre et al. 1996, Priante Filho et al. 2004, Rodrigues et al. 2013). Sun et al. (2010) studying in loblolly pine plantations, North Carolina, USA and Lenters et al. (2011) in a study of wetlands in Nebraska, USA found similar patterns with increasing $\mathrm{H}$ and $\mathrm{LE}$ decreased in the dry season. This indicates the great change in the values of these fluxes with less abrupt changes in the rainy season indicating that rainfall is a factor in the patterns of the energy flux in the region. 


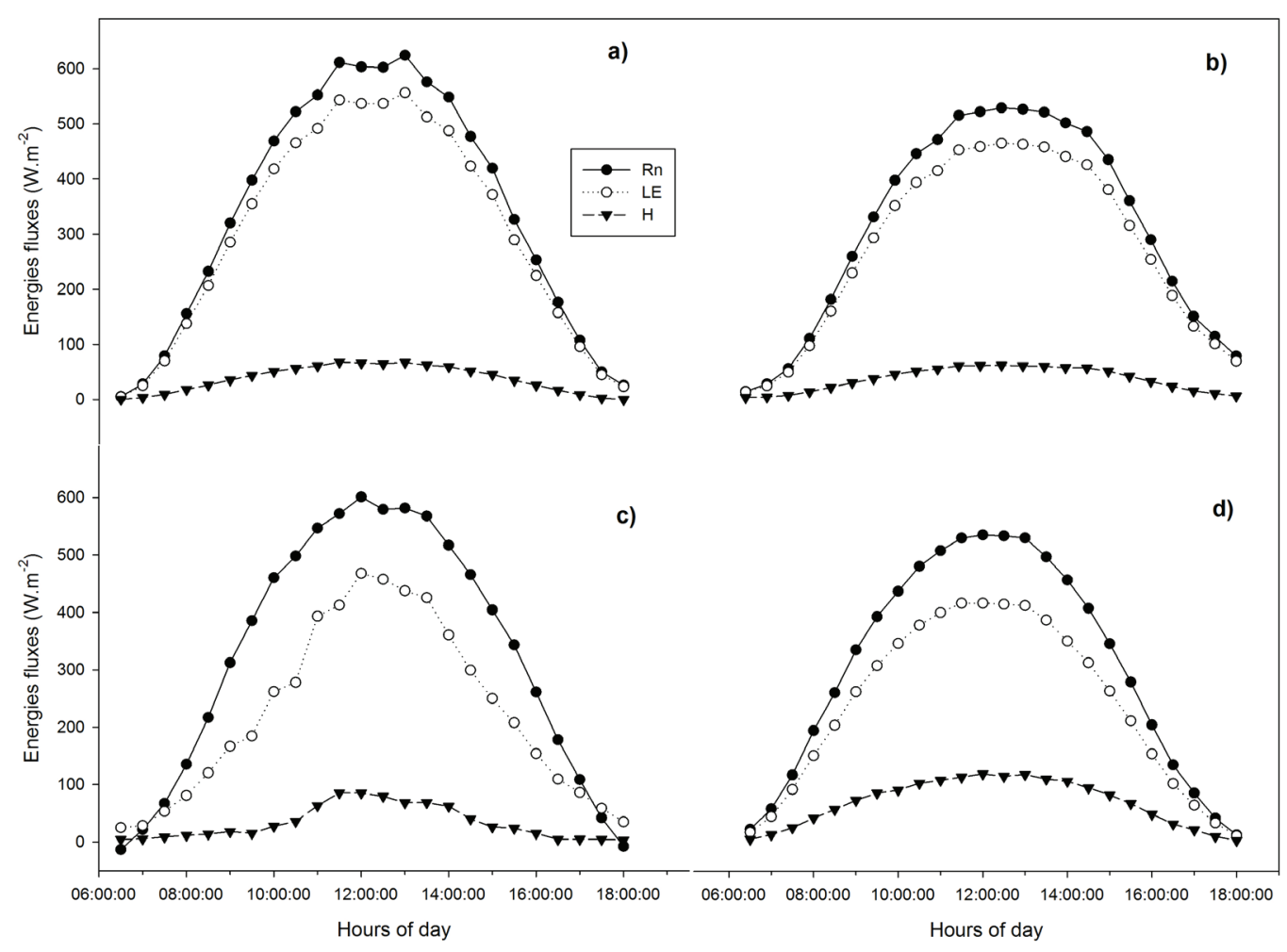

Figure 4 - Patters of the hourly energy partition in wet seasons for the Brazilian Wetlands in Mato GrossoBrazil during the study period, 2007 (a), 2008 (b), 2009 (c) and 2010 (d).

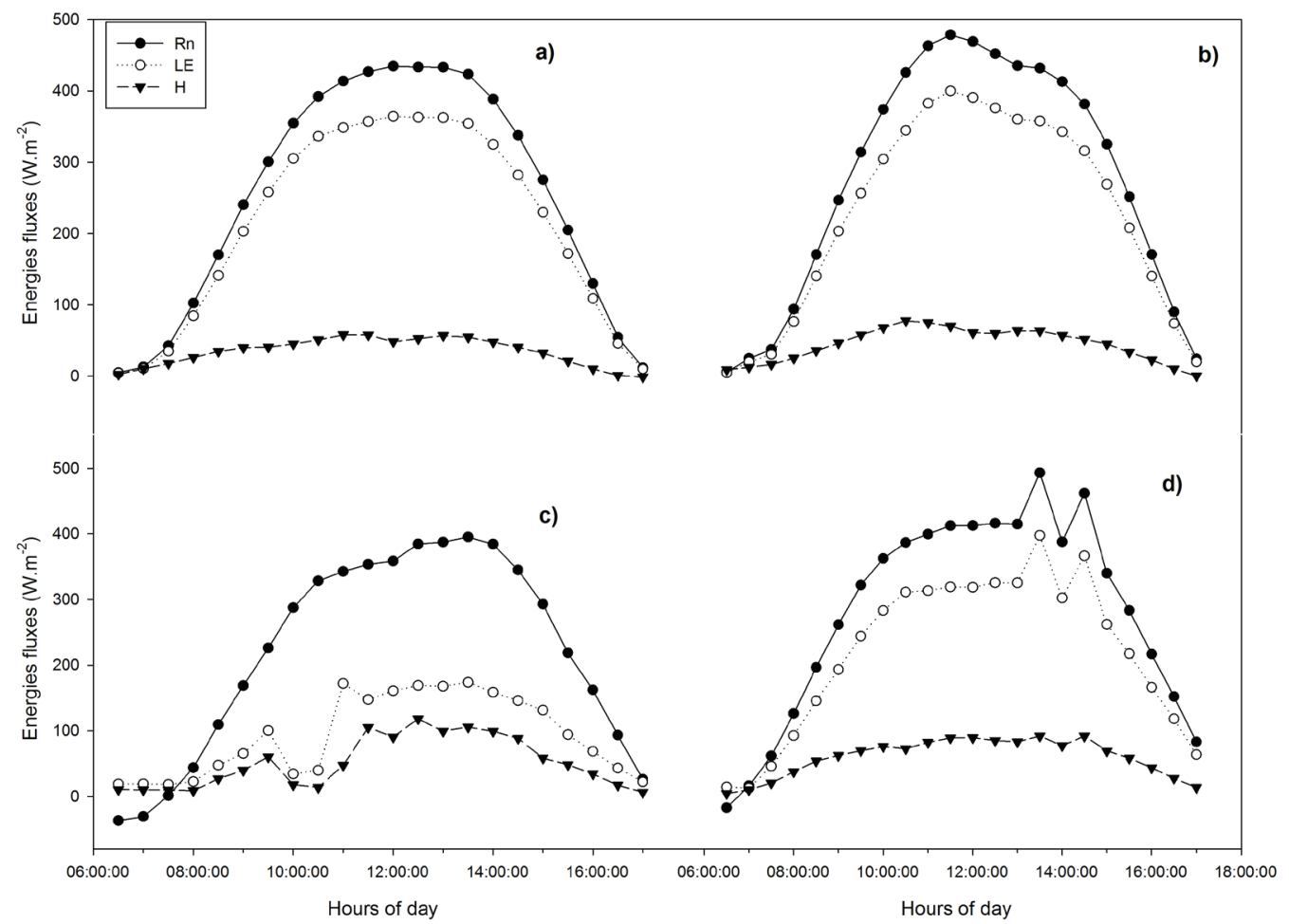

Figure 5 - Patters of the hourly energy partition in dry seasons for the Brazilian Wetlands in Mato GrossoBrazil during the study period, 2007 (a), 2008 (b), 2009 (c) and 2010 (d). 
Sanches et al. (2011) found similar patterns in the same study area. These authors have reported that given the relatively high level of water at the study site, the decline in LE during the dry period was presumably caused most by a decline in soil evaporation rather than by a decrease in transpiration of trees (due to the increased amount of flood water during the rainy season). Similar results were observed in wetlands of Everglade humid subtropical (Shoemaker and Sumner 2006). These results suggest that patterns of LE for Cambarazal are more similar to the lowland Amazon rainforest than other tropical forests in the same region (Rodrigues et al. 2011). These authors also report that even in times with little or no precipitation the Cambarazal has a high transpiration rate probably the trees of the site can absorb deep water, maintaining a high perspiration even in periods of low rainfall (Rodrigues et al. 2011).

Other environmental factors influencing $\mathrm{H}$ and LE vary seasonally and are at least partly under human control. Higher water content in the atmosphere and in the soil, and larger solar radiation during this season contribute to soil evaporation and plant transpiration, in turn, leading to greater LE flux at the site.

In all periods the sum of $\mathrm{LE}$ and $\mathrm{H}$ were above $90 \%$ of $\mathrm{Rn}$, indicating that these variables are responsible for the consumption of almost all the available energy balance partition.

\section{REGRESSIONS BETWEEN WIND SPEED, LE AND H}

Hourly interaction between wind speed and energy fluxes in Brazilian Wetlands - Mato Grosso - Brazil were done through linear regression between wind speed, LE and H. Figures 6 and 7 present Linear regression in wet seasons.

According to Figures 6 and 7 there was a linear interaction between wind speed and energies flux partition: $\mathrm{LE}$ and $\mathrm{H}$ in all wet seasons. In all seasons presented linear regression with positive angular coefficient indicating positive correlation between wind speed, LE and H, i.e. as there was an increase in wind speed LE and also increased about regression, in all wet seasons occurred high values of $\mathrm{R}^{2}$. Figures 8 and 9 present Linear regression in dry seasons.

Linear regressions between wind speed, LE and $\mathrm{H}$ in dry seasons were similar in wet seasons presenting positive correlation and high values $R^{2}$, except in 2010. So, the wind speed is an important factor in latent heat flux and sensible heat flux in wet and dry seasons. Table II presents significance $(p<0.05)$ of regression coefficient indicated in Figures $6,7,8$ and 9. Note that in all periods studied (except dry season of 2010) coefficients $\mathrm{a}$ and $\mathrm{b}$ present statistical significance according to confidence interval, indicating that linear regressions presented are reliable and can be used in interactions studies about wind speed, LE and $\mathrm{H}$.

These results suggest there was a linear interaction between wind speed and LE, wind speed and $\mathrm{H}$ in wet and dry seasons in Brazilian Pantanal. So, maybe is possible a greater understand about patterns energies partition: $\mathrm{LE}$ and $\mathrm{H}$ and their interaction with other micrometeorological variables.

\section{CONCLUSIONS}

The patterns energies fluxes: Rg, Rn, LE and $H$ presented similar in all period with higher values around noon and lower values in early morning and late afternoon.

Wind speed presents similar patterns of air temperature with higher values between 10:00 and 15:00, while relative humidity presented inverse patterns with higher values in early morning and lower values coinciding with maximum air temperature values.

The patterns of LE and $\mathrm{H}$ presented higher LE values in all periods, including dry seasons. The sum of LE and $\mathrm{H}$ was above $95 \%$ of $\mathrm{Rn}$ in all periods, indicating that these variables are responsible for the consumption of almost all the available energy balance partition. 


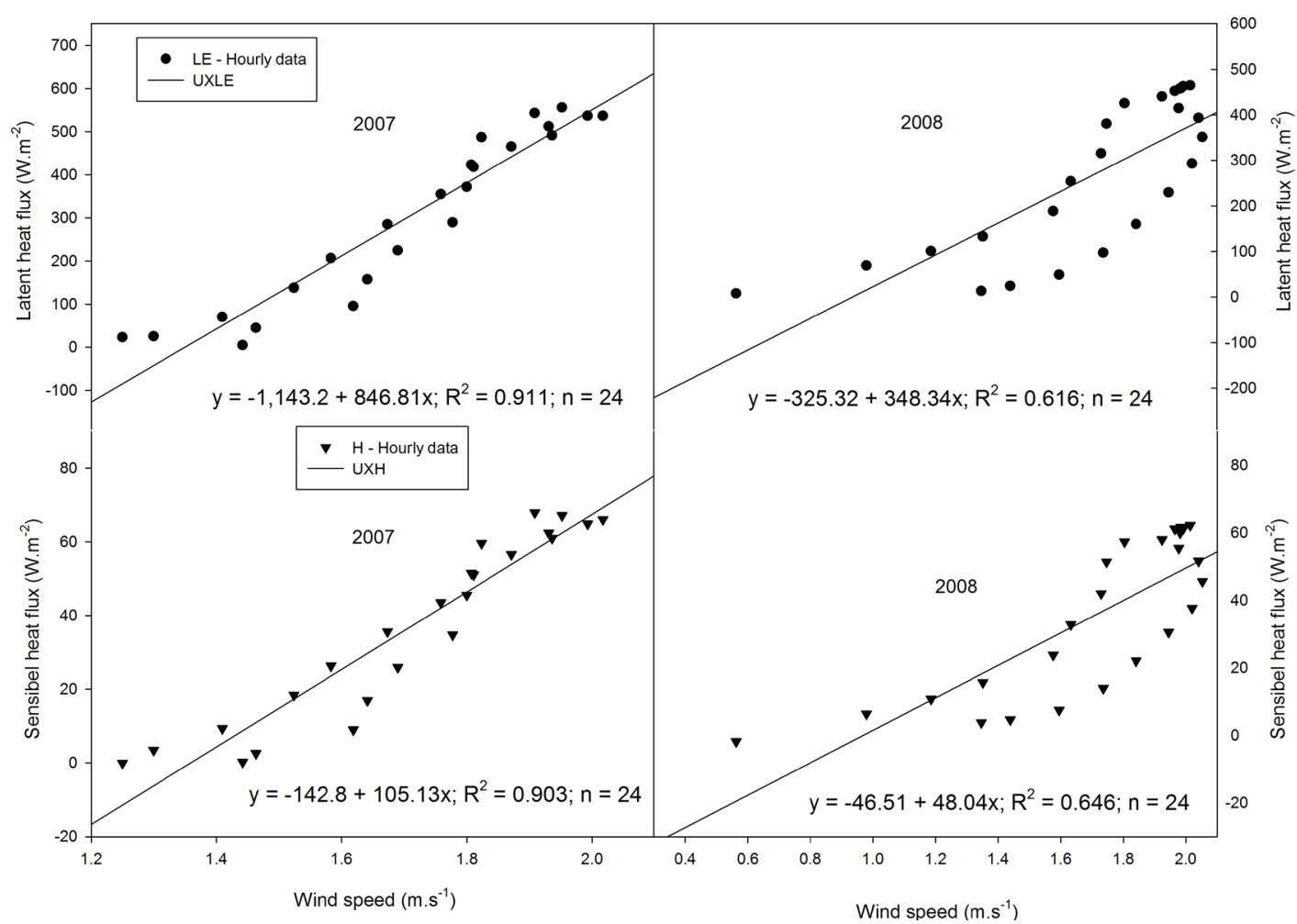

Figure 6 - Linear regression (+95\% confidence interval) between wind speed, latent heat flux and sensible heat flux in wet seasons in 2007 and 2008 for the Brazilian Wetlands in Mato Grosso-Brazil.

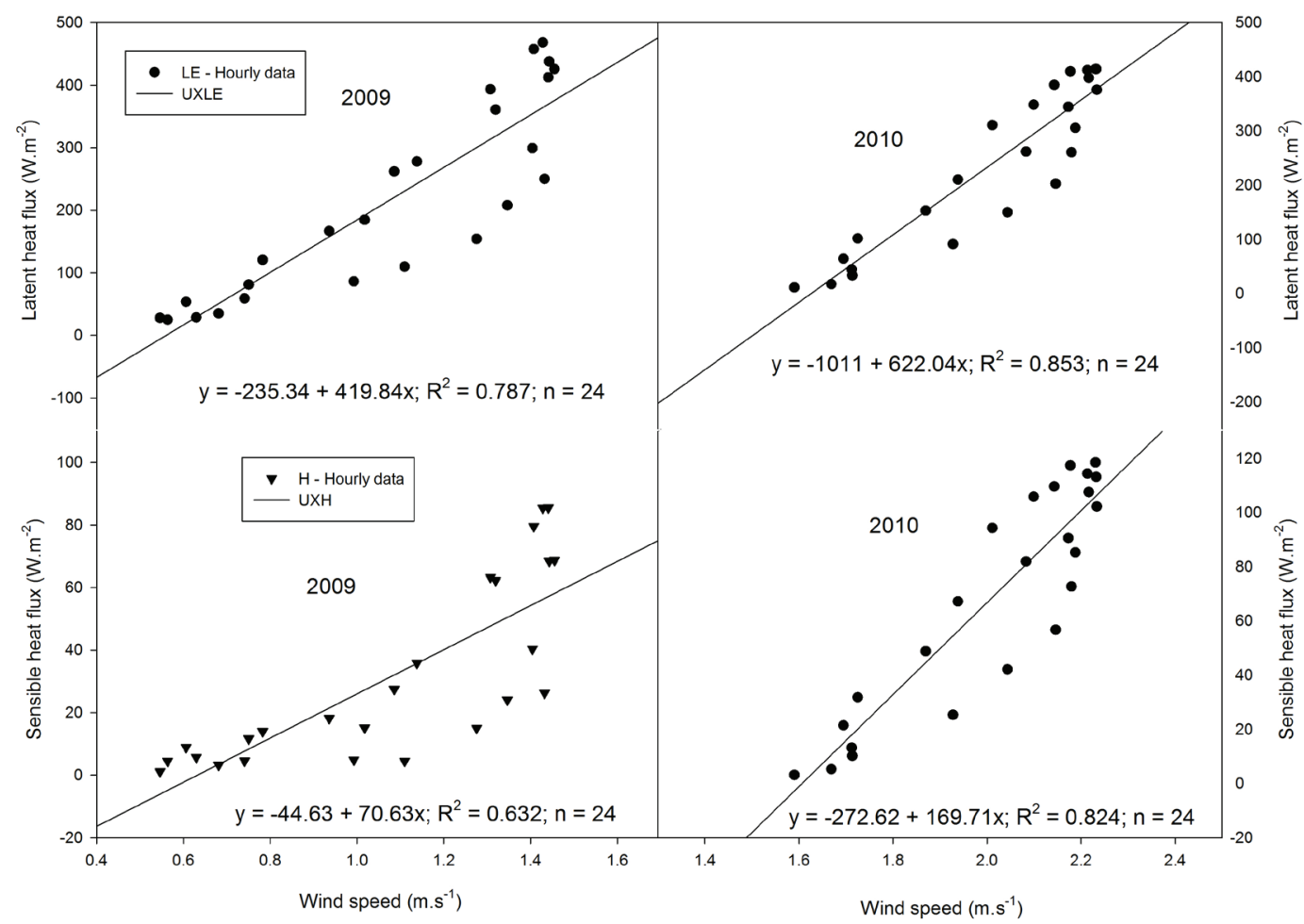

Figure 7 - Linear regression ( $+95 \%$ confidence interval) between wind speed, latent heat flux and sensible heat flux in wet seasons in 2009 and 2010 for the Brazilian Wetlands in Mato Grosso-Brazil. 


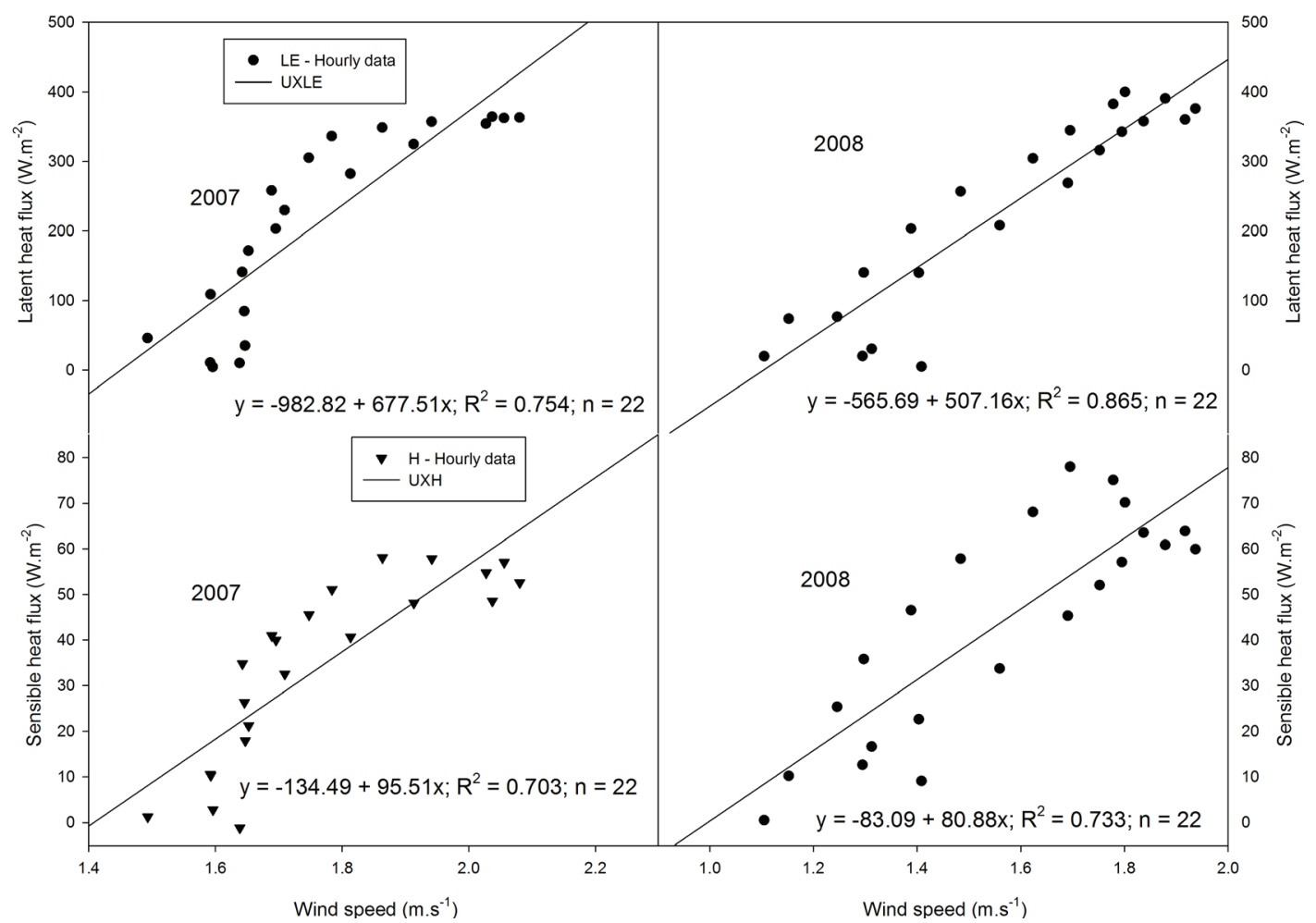

Figure 8 - Linear regression (+95\% confidence interval) between wind speed, latent heat flux and sensible heat flux in dry seasons in 2007 and 2008 for the Brazilian Wetlands in Mato Grosso-Brazil.

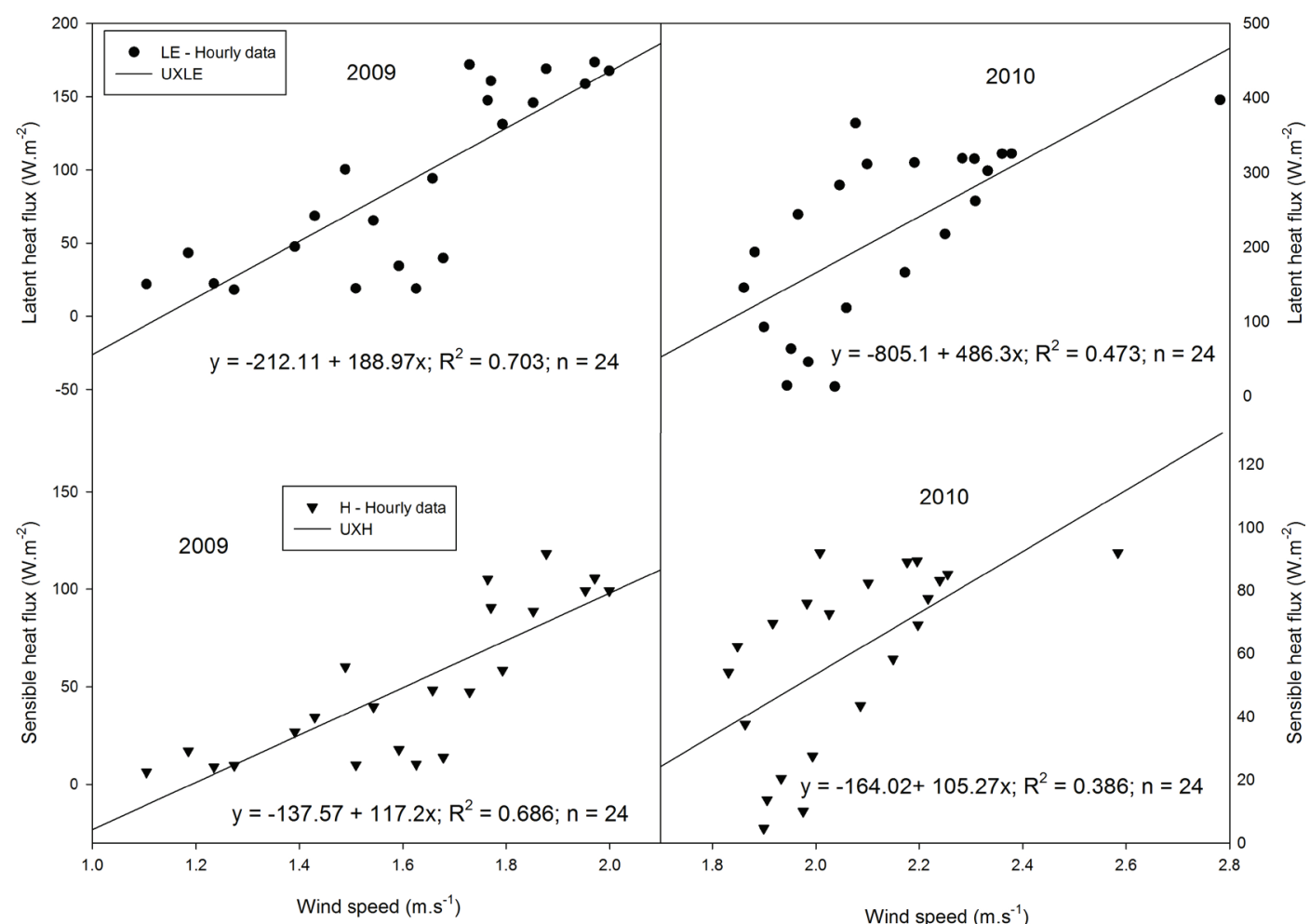

Figure 9 - Linear regression ( $+95 \%$ confidence interval) between wind speed, latent heat flux and sensible heat flux in dry seasons in 2009 and 2010 for the Brazilian Wetlands in Mato Grosso-Brazil. 


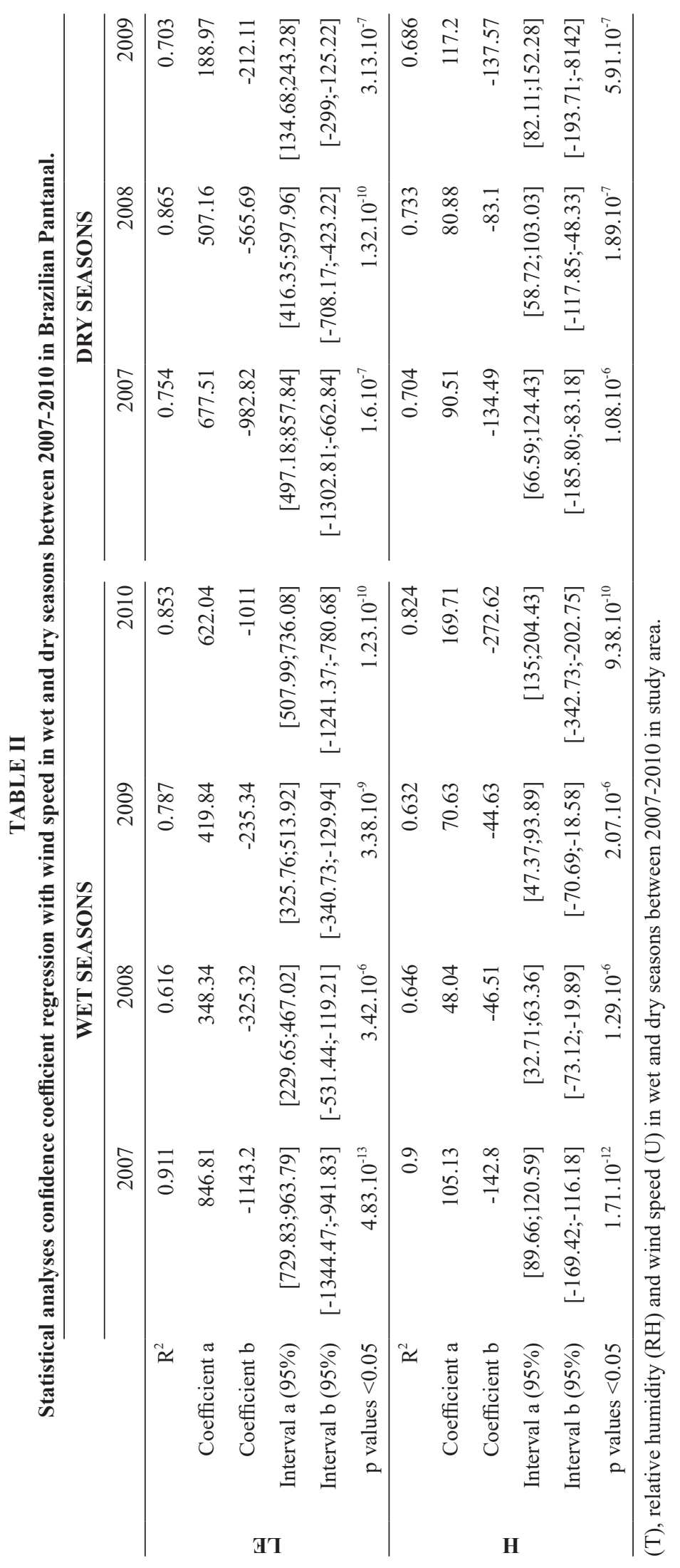


Linear regression analyses present positive interactions between wind speed and LE, wind speed and $\mathrm{H}$. Confidence coefficient regression analyses present statistical significance in all wet and dry seasons, except dry season of 2010, suggest the LE and $\mathrm{H}$ interaction with other micrometeorological variables.

\section{ACKNOWLEDGMENTS}

The authors thank Programa Nacional de PósDoutorado (PNPD/CAPES), Coordenação de Aperfeiçoamento de Pessoal de Nível Superior (CAPES), Conselho Nacional de Desenvolvimento Científico e Tecnológico (CNPq) for Scholarship and Fundação de Amparo à Pesquisa do Estado de Mato Grosso (FAPEMAT) through the Programa de Apoio a Núcleos de Excelência (PRONEX) for financial support to the research project process no. 823971.

\section{REFERENCES}

ALVES I AND PEREIRA LS. 2000. Modelling surface resistance from climatic variables? Agr Water Manage 42(1): 371-385.

AMIRO B. 2009. Measuring boreal forest evapotranspiration using the energy balance residual. J Hydrol 366: 112-118.

BALA G, CALDEIRA K, WICKETT M, PHILLIPS TJ, LOBELL DB, DELIRE C AND MIRIN A. 2007. Combined climate and carbon-cycle effects of large-scale deforestation. Proc Natl Acad Sci USA 104: 6550.

CHEN S, CHEN J, LIN G, ZHANG W, MIAO H, WEI L, HUANG J AND HAN X. 2009. Energy balance and partition in Inner Mongolia steppe ecosystems with different land use types. Agr Forest Meteorol, p. 1800-1809.

CURADO LFA, MUSIS CR, CUNHA CR, RODRIGUES TR, PEREIRA VMR, NOGUEIRA JS AND SANCHES L. 2016. Modeling the reflection of Photosynthetically active radiation in a monodominant floodable forest in the Pantanal of Mato Grosso State using multivariate statistics and neural networks. An Acad Bras Cienc 88: 1387-1395.

CURADO LFA NOGUEIRA JS, SANCHES L, BIUDES MS AND RODRIGUES TR. 2012. Interannual Variability of Energy Flux in Atmospheric Instability Conditions at Pantanal of Mato Grosso-Brazil. Atmos Clim Sci 2: 518-524.

CURADO LFA, NOGUEIRA JS, SANCHES L, RODRIGUES TR, LOBO FA AND BIUDES MS. 2014. Inter Seasonality of the Energy Fluxes in Brazilian Savana-Mato GrossoBrazil. Atmos Clim Sci (Online) 4: 219-230.
DADIC R, MOTT R, LEHNING M, CARENZO M, ANDERSON B AND MACKINTOSHA. 2013. Sensitivity of turbulent fluxes to wind speed over snow surfaces in different climatic settings. Adv Water Resour 55: 178-189.

DAMASCENO-JÚNIOR GA, SEMIR J, DOS SANTOS FAM AND DE LEITÃO-FILHO HF. 2005. Structure, distribution of species and inundation in a riparian forest of rio Paraguai, Pantanal, Brazil. Flora 200: 119-135.

DANELICHEN VHM, MACHADO NG, BIUDES MS AND SOUZA MC. 2013. TRMM satellite performance in estimated rainfall over the midwest region of Brazil. Rev Bras Meteorol 12: 22-31.

DA ROCHA HR, GOULDEN ML, MILLER SD, MENTON MC, PINTO LDVO, DE FREITAS HC AND SILVA FIGUEIRA AM. 2004. Seasonality of water and heat fluxes over a tropical forest in eastern Amazonia. Ecol Appl 14: S22-S32.

FALGE E ET AL. 2005. Comparison of surface energy exchange models with eddy flux data in forest and grassland ecosystems of Germany. Ecol Model 188: 174-216.

GIAMBELLUCA TW, SCHOLZ FG, BUCCI SJ, MEINZER FC, GOLDSTEIN G, HOFFMANN WA, FRANCO AC AND BUCHERT MP. 2009. Evapotranspiration and energy balance of Brazilians Savannas with contrasting tree density. Agr Forest Meteorol 149: 1365-1376.

HAASE R AND HAASE P. 1995. Above-ground biomass estimates for invasive trees and shrubs in the Pantanal of Mato Grosso, Brazil. For Ecol Manage 73: 29-35.

HAYASHI MMS, CAMPELO JÚNIOR JH, PRIANTE FILHO N, NOGUEIRA JS AND VOURLITIS GL. 2002. Balanço de energia da Crotalaria juncea L. no período seco e no período úmido do ano, em condições de Cerrado. Rev Bras Agrometeorol 10(2): 197-205.

JUANG J-Y, KATUL GG, SIQUEIRA MBS, STOY PC AND NOVICK KA. 2007. Separating the effects of albedo from eco-physiological changes on surface temperature along a successional chronosequence in the Southeastern US. Geophys Res Lett 34, (L21408), doi:10.1029/2007GL031296.

JUNK WJ, NUNES DA CUNHA C, WANTZEN KM, PETERMANN P, STRÜSSMANN C, MARQUES MI AND ADIS J. 2006. Biodiversity and its conservation in the Pantanal of Mato Grosso, Brazil. Aquat Sci 68: 278309.

LAW BE, FALGE E, GU L, BALDOCCHI DD, BAKWIN P, BERBIGIER P, DAVIS K, DOLMAN AJ, FALK M AND FUENTES JD. 2002. Environmental controls over carbon dioxide and water vapor exchange of terrestrial vegetation. Agr Forest Meteorol 113: 97-120.

LENTERS JD, CUTRELL GJ, ISTANBULLUOGLU E, SCOTT DT, HERRMAN KS, IRMAK A AND EISENHAUER DE. 2011. Seasonal energy and water balance of a Phragmites australis-dominated wetland in the 
Republican River basin of south-central Nebraska (USA). J Hydrol 408: 19-34.

MALHI Y, PEGORARO E, NOBRE AD, PEREIRA MGP, GRACE J, CULF AD AND CLEMENT R. 2002. The energy and water dynamics of a central Amazonian rain forest. J Geophys Res 107, LBA 45-1.

MARKS D AND DOZIER J. 1992. Climate and energy exchange at the snow surface in the alpine region of the Sierra Nevada. 2. Snow cover energy balance. Water Resour Res 28(11): 3043-3054.

MARKS D AND WINSTRAL A. 2001. Comparison on snow deposition, the snow cover energy balance, and snowmelt at two sites in a semiarid mountain basin. J Hydrometeorol 2(3): 213-227.

NOBRE DA, DOLMAN AJ AND GASH JHC. 1996. The large scale biosphere - atmosphere experiment in Amazonia. Contise experimental plan. The LBA Sci Plann Group, 44 p.

NOORMETS A, EWERS B, SUN G, MACKAY S, ZHENG D, MCNULTY SG AND CHEN J. 2006. Water and carbon cycles in heterogeneous landscapes: an ecosystem perspective. In: Chen J, Saunders SC, Brosofske KD and Crow TR (Eds), Linking Ecology to Landscape Hierarchies. Nova Publishing, Carbondale, IL, USA, p. 89-123.

NOVAIS JWZ, RODRIGUES TR, CURADO LFA, DE OLIVEIRA AG, PAULO SR AND NOGUEIRA JS. 2012. Variabilidade Sazonal Horária Das Propriedades Térmicas Em Gleissolo Háplico No Norte Do Pantanal. Semin: Cien Agrar (Impresso) 33: 2563-2570.

PEREIRA AR, ANGELOCCI LR AND SENTELHAS PC. 2002. Agrometeorologia: fundamentos e aplicações. Guaíba: Agropec, 478 p.

PEREZ PJ, CASTELLVI F, IBAÑES M AND ROSELL JI. 1999. Assessment of reliability of Bowen ratio method for partitioning fluxes. Agr Forest Meteorol 97: 141-150.

PEREZ PJ, CASTELLVI F AND MARTÍNEZ-COB A. 2008. A simple model for estimating the Bowen ratio from climatic factors for determining latent and sensible flux. Agr Forest Meteorol 148: 25-37.

PIELKE RA, ADEGOKE J, BELTRÁN-PRZEKURAT A, HIEMSTRA CA, LIN J, NAIR US, NIYOGI D AND NOBIS TE. 2007. An overview of regional land-use and land-cover impacts on rainfall, 2007. Tellus B 59(3): 587-601.

PRIANTE FILHO N ET AL. 2004. Comparison of the mass and energy exchange of a pasture and a mature transitional tropical forest of the southern Amazon Basin durin a seasonal transition. Glob Chang Biol 10: 863-876.
RESTREPO NC AND ARAIN MA. 2005. Energy and water exchanges from a temperate pine plantation forest. Hydrol Process 19: 27-49.

RODRIGUES TR, CURADO LFA, NOVAIS JWZ, DE OLIVEIRA AG, PAULO SR, BIUDES MS AND NOGUEIRA JS. 2011. Distribuição dos componentes do balanço de energia do Pantanal Mato-grossense. Rev de Ciên Agro-Amb (Online) 9(2): 165-175.

RODRIGUES TR, DE PAULO SR, NOVAIS JWZ, CURADO LFA, NOGUEIRA JS, DE OLIVEIRA RG, LOBO FA AND VOURLITIS GL. 2013. Temporal patterns of energy balance for a Brazilian tropical savanna under contrasting seasonal conditions, Int $\mathrm{J}$ Atmos Sci, $\mathrm{n}^{\circ} 326010,9$ pages, doi:10.1155/2013/326010.

RODRIGUES TR, VOURLITIS GL, LOBO FA, DE OLIVEIRA RG AND NOGUEIRA JS. 2014. Seasonal variation in energy balance and canopy conductance for a tropical savanna ecosystem of south-central Mato Grosso, Brazil. J Geophys Res Biogeosci 119: 1-13.

RODRIGUES TR, VOURLITIS GL, LOBO FA, SANTANNA FB, ARRUDA PHZ AND NOGUEIRA JS. 2016. Modeling canopy conductance under contrasting seasonal conditions for a tropical savanna ecosystem of south central Mato Grosso, Brazil. Agr Forest Meteorol 218-219: 218-229.

SANCHES L, VOURLITIS GL, ALVES MC, PINTO JUNIOR OB AND NOGUEIRA JS. 2011. Seasonal Patterns of Evapotranspiration for a Vochysia divergens Forest in the Brazilian Pantanal. Wetlands 31: 1215-1225.

SHOEMAKER WB AND SUMNER DM. 2006. Alternate corrections for estimating actual Wetland evapotranspiration from potential evapotranspiration. Wetlands 26: 528-543.

SUN G, NOORMETS A, GAVAZZI MJ, MCNULTY SG, CHEN J, DOMEC JC, KING JS, AMATYA DM AND SKAGGS RW. 2010. Energy and water balance of two contrasting loblolly pine plantations on the lower coastal plain of North Carolina, USA. For Ecol Manage 259: 1299-1310.

VON RANDOW C ET AL. 2004. Comparative measurements and seasonal variations in energy and carbon exchange over forest and pasture in South West Amazonia. Theor Appl Climatol 78: 5-26.

VOURLITIS GL, NOGUEIRA JDS, LOBO FDA, SENDALL KM, DE PAULO SR, DIAS CAA, PINTO OBP AND DE ANDRADE NLR. 2008. Energy balance and canopy conductance of a tropical semi-deciduous forest of the southern Amazon Basin. Water Resour Res 44: W03412. 